- biology at the Open University in Milton Keynes, UK, organized the 2002 moratorium call with his wife Hilary Rose, a sociologist and emeritus professor at the University of Bradford. He claims that in the past ten years the campaign has "gone on expanding". Although there are no solid data on its effects, he says that moves by the Israeli government to counter it - such as 2011 legislation that outlaws boycott calls within Israel — are telling. "That shows it's having an impact," he says.

Other researchers question whether science in Israel has been significantly affected. The country collaborates with many institutions in Europe and the United States, and even with some academics in the occupied Palestinian territories. "I personally have not suffered from any boycott activity. I have relationships and collaborations with British scientists and scientists all over the world," says Ruth Arnon, an immunologist at the Weizmann Institute of Science in Rehovot, Israel, and president of the Israel Academy of Sciences and Humanities in Jerusalem, who has strongly criticized Hawking's decision and the boycott movement. "There may have been some who have been affected, but I don't know of any real effect."

Hawking's announcement is a "huge development" that may aid the boycott campaign in the United States, where it has traditionally not had much traction, says Jess Ghannam, a clinical psychiatrist at the University of California, San Francisco, and a member of the organizing committee of the US Campaign for the Academic and Cultural Boycott of Israel. "This is a real turn"There may
have been some
who have been
affected, but I
don't know of
any real effect." ing point, in terms of bringing attention to this issue."

Supporters of a boycott draw parallels between their movement and the campaigns for an aca-

demic boycott of South Africa that occurred during that country's apartheid regime. But critics say that Israel is being unfairly singled out, arguing that institutions and conferences in other nations with questionable humanrights records are not being boycotted. Some say that the focus on Israel is rooted in antiSemitism, a charge that Rose and others strongly deny.

In another recent event, a UK employment tribunal ruled on 22 March in favour of the University and College Union (UCU), a trade union for higher-education teachers, in a case brought against it in 2011. Ronnie Fraser, a mathematics teacher and a UCU member, had alleged "institutional anti-Semitism" that was in part due to repeated votes at the union's annual meetings to boycott Israeli academic institutions. Although the union concluded in 2007 , on the basis of legal advice, that a boycott would be unlawful, votes at subsequent meetings have approved related motions, such as discussing Palestinian calls for a boycott.

The tribunal dismissed Fraser's complaint, calling it "an impermissible attempt to achieve a political end by litigious means". Some academics fear that this could embolden the boycott movement. David Hirsh, a sociologist who researches anti-Semitism at Goldsmiths, University of London, and who helped to spearhead Britain's anti-boycott Engage campaign, says that it gives a judicial stamp to the idea that such a boycott is not anti-Semitic. "That's really damaging," he says.

Meanwhile, Richard Axel, a neuroscientist at Columbia University in New York, says that he will go ahead with plans to attend the Jerusalem meeting next month. "I do have serious concerns over the Israeli occupation of Palestinian territories. I'm deeply troubled by it," he says. "But I do not feel an academic boycott of Israeli universities will in any significant way make progress to a resolution of that crisis." -

\title{
Meeting targets lab lapses
}

\section{Attendees search for ways to tackle misconduct and sloppy science.}

\section{BY RICHARD VAN NOORDEN}

$\mathrm{E}$ very conference has its own brand of comedy, and the humour is deliciously dark when the subject is misconduct. James Kroll, who investigates misconduct allegations at the US National Science Foundation, knew he would get a laugh with his classic "excuses for plagiarism" slide, which included one scientist who blamed acid reflux, and another who was "distracted by bird vocalizations".

But any 'would-you-believe-that?' jocularity at the 3rd World Conference on Research Integrity, held last week in Montreal, Canada, was light relief from the serious concerns that attendees had come to tackle. Allegations of misconduct are rising, retractions are on the up and concern is growing that sloppy lab practices are leading to unreliable research.

Experts debate whether the trends represent real increases or simply growing awareness. But attendees at the meeting were brimming with plans to combat problems ranging from out-and-out fraud to selective publication of experiments. Among the potential solutions are spot audits of research data; independent replication of results; requirements for data-sharing; ethics codes and training; forced accountability for institutions; and greater protection for whistle-blowers. Still, the attendees acknowledged that it is hard to measure whether these strategies work - and hardest of all to provide incentives for change in a system in which scientists are rewarded for speedy success.

"We know that research misconduct is more common than expected," Nicholas Steneck, an ethicist at the University of Michigan in Ann Arbor, told the meeting of more than 360 attendees from 45 countries, "but we don't know if it is getting any worse and whether it can be prevented or deterred."

In recent years, the number of misconductrelated inquiries has spiked at national oversight and advisory bodies (see 'Questions of integrity'), and at research journals. Veronique Kiermer, executive editor of Nature Publishing
D NATURE.COM See Nature's special on reproducible research: go.nature.com/huhbyr
Group in New York, says that anonymous allegations are growing, "taking a toll" on editors who must investigate them, although many turn out to be ill-founded.

Lots of journals already scan manuscripts with plagiarism software. Bernd Pulverer, chief editor of The EMBO Journal, said at the meeting that his publication began systematic pre-publication examination of images in papers last November; around $4 \%$ contain "serious manipulations", he said. But more discoveries do not mean that more misconduct is occurring. The Journal of Cell Biology has consistently revoked about $1 \%$ of accepted publications for image manipulation over the past decade, with no upward trend.

Meta-analyses suggest ${ }^{1}$ that $1-2 \%$ of scientists admit to misconduct in anonymous surveys. A similar proportion admit to plagiarism, and $31 \%$ say that they have witnessed plagiarism by others, according to unpublished work by Daniele Fanelli, who studies science policy and misconduct at the University of Edinburgh, UK. "The field needs quantitative research - otherwise, we are just talking 


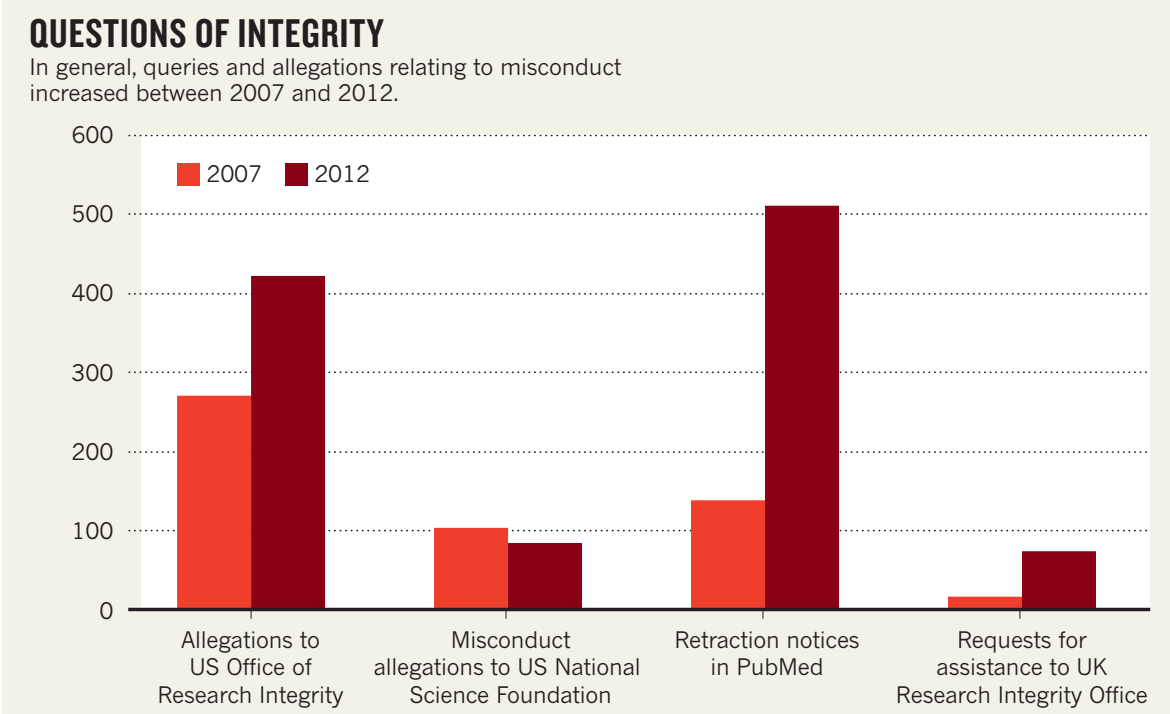

around our own assumptions," he says. He thinks that analyses of the literature, for example to see when data look statistically improbable, will help to spot misconduct.

A new watchdog website, Integru.org, could also ferret out dishonesty. Launched last year to highlight evidence of plagiarism by scientists in Romania (see Nature 488, 264-265; 2012), the site is now widening its focus so that anyone can submit cases in which they suspect plagiarism. The hope is that volunteer academics and the public will cooperate, using tools on the Integru platform to resolve each case.

For all the damage done by outright misconduct, meeting attendees said, lazy or sloppy research is a bigger concern. Institutions are now pouring resources into educating researchers about responsible conduct, but there is little evidence that the training is effective, according to the preliminary results of a systematic review presented at the meeting by Ana Marušić of the University of Split in Croatia.

Independent replication of studies - if it can be funded - could help to make sure that the literature is reliable. This idea has gained ground in the past year, after drug companies such as Bayer HealthCare in Leverkusen, Germany, and Amgen in Thousand Oaks, California, reported that they had trouble replicating published biomedical results ${ }^{2}$. One studyvalidation mechanism, the Reproducibility Initiative based in Palo Alto, California, will task third parties with replication. This year, it has secured funding to replicate some $50 \mathrm{key}$ biomedical experiments at a cost of around US \$20,000 each, said its founder, Elizabeth Iorns (see Nature 492, 335-343; 2012). Almost 1,900 scientists have volunteered to have their results retested, she said.

Many ideas put forward at the conference - such as independent audits of raw data are already in practice in clinical research, but not in bench science unless lab heads choose to enforce them. As far back as 1987, Adil
Shamoo, a biochemist at the University of Maryland in Baltimore, argued in Nature that scientists would have to expect routine dataauditing ${ }^{3}$. But the idea has never been accepted by the community, says Shamoo, who is also editor-in-chief of Accountability in Research.

One emerging concern is that modern research increasingly involves international collaborations. Melissa Anderson, who studies scientific integrity at the University of Minnesota in Minneapolis, says that integrity efforts will not be robust unless countries adopt common rules for factors such as ethical conduct and authorship. Simon Godecharle, a biomedical ethicist at the Catholic University of Leuven in Belgium, agrees. "Not one definition of research integrity or misconduct is the same in any two European countries" apart from Denmark and Norway, he says.

"Many countries are just at the start of their oversight integrity policies," said Anderson. But compared with the first world meeting, six years ago in Lisbon, said Steneck, countries' awareness that they need to foster integrity is at an all-time high. The difficulty now, he said, is in making sure that integrity codes and training requirements are actually affecting lab practice. "Everything we're doing is above where the researchers live their day-to-day lives - and the challenge is to reach them."

1. Fanelli, D. PLOS ONE 4, e5738 (2009).

2. Begley, C. G. \& Ellis, L. M. Nature $483,531-533$ (2012).

3. Shamoo, A. \& Annau, Z. Nature 327, 550 (1987).

\section{CORRECTION}

The News story 'Targeted drugs to tackle hepatitis C' (Nature 497, 18-19; 2013) wrongly implied that the US Preventive Services Task Force considers financial costs when evaluating the risks and benefits of screening. It does not. 